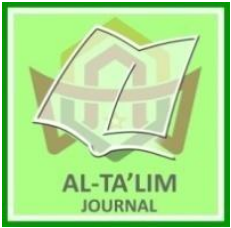

AL-TA'LIM JOURNAL, 25 (2), 2018, (97-107)

(Print ISSN 1410-7546 Online ISSN 2355-7893)

Available online at http://journal.tarbiyahiainib.ac.id/index.php/attalim

\title{
Multicultural Awareness and Practices among Malaysian Primary School Teachers
}

Received: $26^{\text {th }}$ April 2018; Revised:07 ${ }^{\text {th }}$ May 2018; Accepted: $24^{\text {th }}$ July 2018

Permalink/DOI: http://dx.doi.org/10.15548/jt.v25i2.446

\section{Qismullah Yusuf}

Universitas Syiah Kuala, Aceh, Indonesia

E-Mail: yusufqismullah@gmail.com

\section{Sangeetha Marimuthu}

Sultan Idris Education University, Malaysia

E-Mail: aksha_mp@yahoo.com

\section{Yunisrina Qismullah Yusuf *)}

Universitas Syiah Kuala, Aceh, Indonesia

E-Mail: yunisrina.q.yusuf@unsyiah.ac.id

\section{*) Corresponding Author}

\begin{abstract}
This study was designed and aimed at identifying the awareness and practices of multicultural awareness among primary school teachers in Malaysia. It attempts to identify their awareness of multicultural concept when dealing with their students and staffs at their school. This awareness was measured by three variables: awareness, knowledge and skills. A number of 41 questions which inquired about the three variables were distributed randomly to 50 primary school teachers in Malaysia. These teachers were from three ethic types of primary schools: Tamil, Chinese and Malay primary schools. The reason for choosing the three different mainstream schools was because they represented the main different multicultural practices in the country. From these participants, five teachers were selected for further interviews to obtain richer data. The findings revealed that the awareness of multicultural education among primary school teachers was still at the medium level. Thus, this study suggests that there should be a multicultural awareness campaign at all schools in Malaysia in order to ensure that each student, no matter from what backgrounds they are from, feel they are part of the Malaysian society as a whole. The study also found that the awareness should start from the home, environment and peer and through parental guidance because school is a bridge between home and the society that will form one Malaysian society to achieve vision 2020 .
\end{abstract}

Keywords: Multicultural awareness; multicultural practices; multicultural education; primary school teachers.

How to cite: Yusuf, Q., Marimuthu, S., \& Yusuf, Y. (2018). Multicultural awareness and practices among Malaysian primary school teachers. Al-Ta Lim Journal, 25(2). doi: http://dx.doi.org/10.15548/jt.v25i2.446

\section{INTRODUCTION}

Malaysia's total population is estimated at 28 million, comprising Malays $(53.3 \%)$, Chinese $(27.5 \%)$, Indians $(7 \%)$, numerous Indigenous peoples $(11 \%)$ and others (1.2\%) (Renganathan, 2009; SweeHock, 2015). Its slogan of "Malaysia Truly Asia" from the Ministry of Tourism and Culture Malaysia covers the multi-ethnic and multicultural society of the country. The national language is Malay and English is the official second language of the country.
Malaysians also have the privilege and option of going to primary or elementary schools that use either Malay, Chinese (Mandarin) or Tamil language as the medium of instruction (Renganathan, 2009; Saravanamuttu \& Wah, 2006).

Based on its multi-ethnic and multicultural society, this study intends to investigate the multicultural awareness and practices among Malaysian primary school teachers. In addition, Manning, Baruth, \& Lee (2017) stated that "multicultural education is 
both a concept and deliberate process designed to teach learners to recognize, accept and appreciate the differences in culture, ethnicity, social class, sexual orientation, religion, special needs and gender". Besides different racial and ethnic heritages, students also take with them to school their varied family and historical backgrounds, perspectives, experiences, expectations, and approaches to learning (Gorski, 2009; McAllister \& Irvine, 2000). These factors will influence children's educational experiences. Furthermore, by understanding and accepting the multicultural system of their school, they can reject any form of oppressions due to diversity (Saleh \& Doni, 2018; Wati, 2013).

The progressively diverse student population necessitates teachers to have an extensive array of skills and knowledge to meet these students' heterogeneous needs (Cole, 2008; Gibson, 2005). Berry, Smylie, \& Fuller (2008); Lickona (2009) argues that it is intolerable for teachers to have little respect for their students because of their diverse cultural differences. Teachers have to be trained on how to prepare and adapt to the school environment with all possible students' differences, and further distinguish the effects that cultural differences can have on their students' education. Teachers who are aware of these effects are known to be more acceptable and open minded towards children's different cultures in the classroom.

Many experts argue that teachers' knowledge and understanding of culture can help all students reach their potential with an equal opportunity to learn. Therefore, this study focuses on primary school pupils in Malaysia since it is the foundation age where the concept of oneness can be shaped and practiced permanently for life, especially, if the concept can be implemented conceptually (religiously, civically and socially) since the early life of children. They should be taught that being diversity is not a barrier to realize the unity of a multicultural country (Abdullah, 2009; Banks, 2009; Kamal, 2013). Family is the first stage where kids are exposed to different aspects of life: religion, beliefs, cultures, ethnic groups, skin colours and languages. Meanwhile, the next stage is the school, where Terenzini, Cabrera, \& Bernal (2001) and Gurin, Dey, Hurtado, \& Gurin (2002) claimed that in traditional face-to-face classrooms multicultural content can better promote student learning, better construct their ethnic identity and cognitive growth, and better develop their understanding amongst different racial and ethnic groups in the student body.

A number of researches have been carried out on teacher preparation programs and on practising teachers to teach diverse student populations. These studies include reflective narrative studies Banks, 2009; Ladson-Billings (2009); McAllister \& Irvine (2000); Neal, McCray, Webb-Johnson, \& Bridgest (2003), action research study using autobiographical data Clark \& Medina (2000), individual case studies (Garmon, 2004), and experimental research studies (Baldwin, Buchanan, \& Rudisill, 2007; Beck \& Kosnik, 2001; Kamal, 2013). CochranSmith \& Fries (2001) alleged that almost every prospective school teacher enter the teacher education program with inaccurate beliefs about diverse student populations. These beliefs are influenced by their background, life experiences, language, family and socio-economic status. All of these researches suggest that teacher preparation course work alone does not provide an adequate foundation for multicultural competencies.

Milner (2005) stated that teacher's education institution is responsible in providing the foundation of multicultural education to the teachers to teach in their future classrooms. However the perspective teacher who has lack of cross-cultural experiences has an overwhelming effect on how they develop their approaches on teaching diverse student populations. Banks (2001) also argued that "when prospective teacher's preconceived beliefs influence what they know about diverse student populations, these students are systematically denied an equitable, socially just and cultural 
education". This causes the teaching strategies in the classroom to be dissimilar to a commitment of diversity and multicultural education because the teachers' awareness and practices about diversity are not adequate (Gay \& Howard, 2000; Grant \& Sleeter, 2006; Pang, 2001; Smith, 2009)

Based on the background, it is urgent to examine the awareness of multiculturalism concept among Malaysian teachers. Accordingly, the research question of this study is: How deep is the concept of multiculturalism among Malaysian teachers? The results of this study can contribute to the plans for preparing primary school teachers to be knowledgeable in multiculturalism. Furthermore, the quantitative and qualitative phenomenological of this study can offer understanding of the primary school teachers on multicultural education and approach in teaching the diverse student population in Malaysians schools. Finally, researchers, academicians and scholars may also develop their understanding on the importance of multicultural education for Malaysian schools to develop a truly Malaysia, that treat all the citizens equally.

\section{METHOD}

\section{Research Instruments}

The questionnaire for this study was adapted from Perkins (2012) who conducted the study among teachers on awareness and knowledge of multicultural teaching among students. Thus, the questions for the questionnaire were amended and refined to suit the contexts of this study. This questionnaire consists of 41 questions and this questionnaire used the 4 point Likert's Scale format to measure the teachers' perception on multicultural awareness and practices. The questionnaire used for this study was validated by the Cronbach Alpha reliability test. The result was 0.06 , which is above the benchmark of 0.05 , and is therefore reliable for further analysis.

Self-administered technique was employed in administering the questionnaire, where the second author of this paper was on site to distribute and to collect the completed forms. Self-administer of questionnaire provides opportunity to create rapport, explain the aim of the study and clarify meanings of ambiguous test items. This technique helped us in increasing the usable rate and the respond rate of the questionnaire. The questionnaire used in this study can be found in Appendix 1.

Based on the factor analysis, the communality value of loading value for each question also showed that all 41 items in the questionnaire obtained the Cronbanch Alpha value or loading value of above 0.50 , which indicated that the value was above the minimum value that was recommended by Sekaran \& Bougie (2016), which was 0.50. Therefore, all items in the questionnaire were at an appropriate level to conduct the research.

Additionally, the idea of the semistructured interviews was adopted in this research for the purposes of eliciting the information from the teachers about their instruction and assessment practices in multicultural classrooms. The interview questions were adopted from Perkins (2012) and the question items were redesigned for the appropriateness of this study. At the end, a number of twelve questions were asked to the teachers. The questions can be found in Appendix 2.

\section{Data Collection}

Before data collection started, the procedure of sampling begins with the identity of the population. The population refers to entire group of people or organization that are of interest to the researcher(s) (Berg, Lune, \& Lune, 2004). The target population of the study was the primary school teachers. The simple random sampling technique was used because every element had an equal chance of being selected as a subject from the population; it also has the least bias and offered the most generalization (Sekaran \& Bougie, 2010). The sample size of this study was 50 teachers. A 
number of 41 questions in the questionnaires were distributed to each primary school teacher that participated for this study. All respondents were given two weeks to complete the questionnaire before we collected them back.

Meanwhile, the interview questions were asked to five selected respondents based on their availability and consent to provide additional descriptions of their multicultural awareness and practices. The eligible participants from the three primary school teachers were those who have been working more than ten years in their schools. All five teachers were also from multi ethnic backgrounds, they were Malays, Chinese and Indian. There was no bias in choosing the respondents for this study, thus their answers can be used to generalize this study. Each of the teachers was interviewed individually after school hours and each interview lasted for about half an hour. Each interview session was recorded using a Sony Xperia Z handphone.

\section{Data Analysis}

This study conducted data analysis using several statistical tools and methods employed from SPSS software, which included factor and reliability analyses to test the goodness of fit of the questionnaire measurement (as explained earlier) and descriptive statistics. The purpose of using descriptive statistics was to describe the respondents' characteristics. Furthermore, the correlation analysis was employed to describe the relationship between the variables and to measure the significance of linear vicariate between the variables (Coakes, 2005b, 2005a). In addition, regression analysis was used to achieve the objective of this study as well as to identify the relationship between the variables and the strengths of this relationship.

Likewise, the results of the interviews were transcribed. Following Bamberg (2012); Hawe, Shiell, \& Riley (2009), the transcripts went through narrative analysis, where we attempted to make sense of the interview results provided by the teachers. Here, we analysed each interview transcripts and looked for meanings. We further compared and contrasted their narratives for interpretations, and finally connected and described them in a novel and insightful way.

\section{RESULTS AND DISCUSSIONS Questionnaire}

When referring to item statistics in the questionnaire, there were three items or variables which were used in this study to measure the teachers' perceptions to the multicultural awareness. They are awareness, knowledge and skills. Based on the reliability analysis, the mean score for awareness was 2.57 and the value of standard deviation for this variable was 0.529 . The means score for knowledge variable is 2.71 and the standard deviation value was 0.318 . Finally the mean score value of skills was 2.93 and the standard deviation value was 0.409 . Thus this study declares that the reliability score that were used for the item variables for this study was at an appropriate level. Furthermore, the Cronbanch Alpha value of the three items was 0.654. Meanwhile the Alpha Based on Standardized Items was 0.675 . As stated by Sekaran and Bougie (2010), the minimum acceptance value of Cronbanch Alpha was 0.5 . In conclusion, the reliability of each variable for this study was at the appropriate standard as recommended by the experts. The variable were further analysed using correlation analysis, which refers to the degree of relationship between variables and regressions which are used to predict dependent variables by using independent variable Hair, Black, Babin, Anderson, \& Tatham (2006). Thus, in this study, we attempted to examine the correlations between awareness, skills and knowledge among the teachers.

Table 1. Summary of Correlation Analysis

\begin{tabular}{llll}
\hline Factor & Awareness & Knowledge & Skills \\
\hline Awareness & 1.00 & & \\
Knowledge & $0.287^{* *}$ & 1.00 & \\
Skills & $0.477^{* *}$ & $0.462^{* *}$ & 1.00 \\
\hline
\end{tabular}


The Process of Correlation Analysis (PCA) was conducted to measure the strength and relationship between variables of this study (Coakes et al., 2010) in order to identify the multicollinearity test. Multicollinearity is defined as the degree to which other variables can explicate a variable in the analysis (Hair, et al., 2010). Thus, Table 1 shows a summary of correlation value between variables that were used in this study. The SPSS outputs indicate that there was a significant relationship between independent variables (awareness, knowledge and skill) at $\mathrm{p}<0.01$. The outcome of correlation value indicates that all value is below 0.01 .

\section{Interview}

From the 12 questions asked to the five teachers, we found that question number 2 received high votes from the respondents, which inquired about "your awareness of other cultures". This indicates that three out of five teachers interviewed were aware of the importance of multicultural education. Their answers depict their awareness of the importance of multicultural knowledge, skills and attitudes when dealing with multi ethnic students in Malaysian classrooms. They preferred the anti-bias multicultural education since it is an "anticipated approach" where teachers can explore their own prior to understanding their students' cultures, customs, and other cultural aspects. On the other hand, all teachers responded negatively to question number 9; this indicates that the teachers still had little knowledge toward the effectiveness of multicultural activities that may contribute to the wellness for Malaysia as a multicultural and multi-ethnic country. They did not agree to the professional beliefs that the multicultural activities can be a bridge to all cultures in Malaysia.

Another three questions that received negative answers from the teachers were questions numbers 7,10 , and 12 . Their answers showed that their awareness on the importance to understand the cultures of students in order that they can design and prepare better teaching materials and methods for teaching at Malaysian schools with multiethnic and multicultural groups were still low. This indicates that they were not prepared for the multicultural activities. However, they informed that they do try to work together with cooperative parents to study their students' different cultural backgrounds. By gaining information from parents, their attempt to create activities helped them to build better relationships with students and parents as well. Some teachers and parents even work together by bringing culturally diverse books and language art materials, toys, home and other equipment, props of dramatic tools that encouraged diversity among students in their classrooms. Thus, overall, they claimed that the teachers' participations in school events in order to give multicultural awareness were not enough. Therefore, the schools must design different strategies in order to increase the teachers' interests in teaching multi-cultural based teaching.

The results of the interviews also revealed the teachers' complaints, in which they failed to concentrate on school activities due to over workloads at their schools. Some of the teachers were exhausted with the various policies implemented by the government that reduced the costs of carrying out education programs. Low attention was given to the welfare of the teachers with higher and higher workloads at the schools.

The findings revealed that the awareness of multicultural education among primary school teachers was still at the medium level. This study found that the first challenge is to educate the primary school students about their own beliefs. Tarman \& Tarman (2011) affirmed that different cultural backgrounds are essential resources that can be utilised to both gain materials and attain knowledge. As a result, teachers must recognize the significance of participating in cultural activities outside of the school because it can increase their cross-cultural understanding. Inviting parents to participate in their children's education at school in specific ways is also another way to gain 
appreciation of different cultures. Sometimes, cultural differences may exclude active participation of parents and students in school functions due to differences between their native cultures and the cultures where the schools are operating. And so, teachers should find ways to build virtuous relationships with parents from different cultural backgrounds (Matuszny, Banda, \& Coleman, 2007).

According to Brown (2007); Gay, (2002), (2010); Weinstein, Tomlinson-Clarke, \& Curran (2004), teaching should be culturally responsive. The terms "culturally responsive teaching" is an education that identifies the prominence of children' cultural situations in all facets of learning and the strategies in this education take along the home and community culture into classroom practices (Ladson-Billings, 2009). Moreover, teachers must learn about the cultural groups that they are teaching in the classrooms. By attaining the skills needed to translate that knowledge into effective teaching and enriched curriculum, and building a global understanding between the majority and minority cultures in their classroom by employing culturally responsive strategies and activities, can improve the results of their teaching to the students (Banks, 2001). Banks (2001) further stated "effective teachers use knowledge of their students' culture and ethnicity as a framework for inquiry and they can organize better when implementing it in their instruction". Therefore, teachers who understand, accept, and adopt multicultural perspectives will promote multicultural in their everyday class room activities.

Another important aspect to represent the teachers' understanding of multicultural education is the classroom setting. Gorski (2009); Villegas \& Lucas (2002) asserted that "an environment that is rich in possibilities for exploring gender, race/ethnicity, and cultures sets the scene for practicing multicultural education". Consequently, to create a diverse environment is an essential step for applying multicultural education (Tarman \& Tarman, 2001). Designing a culturally represented environment may show children what a teacher considers important or not important of aspects of multicultural education.

There are numerous ways to incorporate multiculturalism into the classroom environment, such as by organizing various approaches and educating teachers the standards that are specific to what are needed to be included in their instruction. Although schools may have already provided many teaching materials related to multicultural education, teachers may also create additional materials to merge into their classrooms. Smith (2009) said that multicultural education in classrooms should have materials that represent the backgrounds of the various cultures of the students. Books, music/instruments, dramatic play, story tapes, pictures, labels, and games of cultures that are represented in the classroom developed or written in the local languages are examples of additional materials that can be used in the classrooms. The visual setting of the classrooms should display diversity and eliminate stereotypic materials. To enhance the diversity atmosphere of the classroom, the teachers should exhibit many symbols, signs, pictures, posters, maps, art work, and flags from around the world. A variety of books, magazines, music CDs, songs, etc., from different cultures should also be provided in the classroom, as well as culturally specific puzzles, art materials, dolls, dress-up clothes, pretend foods, games, puppets, etc. These designs or concepts show that the teacher has represented different cultures and shows his/her approach to multicultural understanding in the classroom.

The teachers' beliefs, perspectives and values of the other cultural groups are also important because all of these affect curricula and teaching practices (Garmon, 2004, 2005). When teachers are able to examine and realize their biases and stereotypes, they will recognize how these biases influence their teaching and relationships with children who are culturally diverse and will make attempts for improvement. Ming \& Dukes (2006) pursued the examination of beliefs and values 
as introspection. They alleged that "during this time of self-reflection, teachers analyse their own feelings toward those who are culturally different, determine how it relates to the dominant culture, and think about what frame of reference influences these feelings" (Ming \& Dukes, 2006).

Teachers and family members play an important role in children's lives because they can affect the children's views, conceptions, and behaviours (Gilligan, 2000; Lareau, 2011; Wentzel, 1998). These people have substantial influence in guiding children's learning about cultural differences, either positively or negatively. Therefore, teachers' active intervention through all aspects of daily classroom life can change children's negative concepts about other cultural groups.

A more universal outlook may involve influencing the environment in order to have an effective multicultural and anti-bias curriculum. To achieve this, the teachers must first examine their own knowledge and teaching behaviour, and second, they must examine the values, beliefs, and perspectives of their students (Rogers, 2015; Seefeldt, 1993). According to Ramsey (2004), teachers' challenging and exploring habitual attitudes and beliefs could create a state of cognitive dissonance that may lead to the growth and development of thought.

Truman and Truman (2011) stated teaching culturally different students is more process-oriented than content oriented. The focus here is to establish a more effective instructional relationships and rapport with students from different ethnic, cultural, and racial backgrounds as a foundation to improve educational opportunities and outcomes. Gay \& Howard (2000) reminded that teachers, administrators, and supervisors study about the cultural values and experiences of different cultural groups to determine the attitudes and actions in teaching and learning situations. Likewise, Lee \& Buxton (2010) explained that to teach about cultural pluralism highlights materials development and curriculum design, and is a priority to teacher education, staff development, and classroom instruction (Handhika, 2012).

The next approach to multicultural education is infusion; it combines content and process that mean using culturally pluralistic content, experiences, and perspectives in teaching other knowledge and skills. Gay \& Howard (2000) affirmed that ethnic and cultural materials offer contexts for students to practice and express more general academic and subject matter skills. Early childhood educators nowadays accept that anti-bias multicultural education is a more appropriate approach for young children. This is because the approach emboldens the development of positive attitudes towards others while looking for social justice. Furthermore, it considers multicultural education in terms of the totality of the child's education, not just a part of education and becomes essential to all aspects of daily classroom activities. Specifically, (Gay \& Howard (2000) proposed three approaches that can be generalised from these more specific approaches: teaching content about cultural pluralism, teaching culturally different students, and using cultural pluralism to teach other academic subjects and intellectual skills.

\section{CONCLUSION AND RECOMMENDATIONS}

Based on the results from the questionnaire and interviews with the primary school teachers for this study, the awareness of multicultural education among primary school teachers was still at the medium level. Nevertheless, the interview results show that the teachers are eager to learn and have positive understanding in regard to multicultural education. They are willing to develop their skills to further understand the anti-bias multicultural curriculum approach.

Even though the teachers claimed from the interviews that they still had little knowledge toward the effectiveness of multicultural activities, they do try their best to implement teaching practices and to create environments for multicultural education in 
his/her classroom, such as by incorporating the children's daily life experiences into the daily curriculum at their schools. This daily curriculum incorporates diversity and issues related to ethnicity and culture so that the teacher-child interactions can meet the cultural, as well as individual needs of the students.

The teachers have also used parents' knowledge about their home cultures. Even though still struggling in designing and preparing better teaching materials and methods for teaching multi-ethnic and multicultural groups, they do try to implement some strategies to involve all students in their teaching activities and exercised them through special events, cultural and holiday celebrations by school management. And so, this study suggests that there should be more multicultural awareness campaign at all schools in Malaysia in order to ensure that every teacher and student, no matter from what backgrounds they are from, feel they are part of Malaysian society as a whole. Before school, the awareness should start from home, environment and peer, and through parental guidance.

Yet, this research was conducted with some limitations. Due to the time limit of this research and the availability of the teachers, not many of them were involved in the interviews. For future related research, is expected that more in depth interviews can be conducted with more Malaysian teachers from different ethnic groups and backgrounds. Questionnaires should also be distributed to more teachers so that further comprehensive and wide-ranging information can be obtained on the multicultural awareness and practices among Malaysian primary school teachers.

\section{REFERENCES}

Abdullah, A. C. (2009). Multicultural education in early childhood: Issues and challenges. Journal of International Cooperation in Education, 12(1), 159-175.
Baldwin, S. C., Buchanan, A. M., \& Rudisill, M. E. (2007). What teacher candidates learned about diversity, social justice, and themselves from service-learning experiences. Journal of Teacher Education, 58(4), 315-327.

Bamberg, M. (2012). Narrative analysis. APA Handbook of Research Methods in Psychology, 2, 77-94.

Banks, J. A. (2001). Citizenship education and diversity: Implications for teacher education. Journal of Teacher Education, 52(1), 5-16.

Banks, J. A. (2009). Multicultural education: Dimensions and paradigms. In The Routledge international companion to multicultural education (pp. 29-52). Routledge.

Beck, C., \& Kosnik, C. (2001). From cohort to community in a preservice teacher education program. Teaching and Teacher Education, 17(8), 925-948.

Berg, B. L., Lune, H., \& Lune, H. (2004). Qualitative research methods for the social sciences (Vol. 5). Pearson Boston, MA.

Berry, B., Smylie, M., \& Fuller, E. (2008). Understanding teacher working conditions: A review and look to the future. Report Prepared for the Spencer Foundation. Hillsborough, NC: Center for Teaching Quality.

Brown, M. R. (2007). Educating all students: Creating culturally responsive teachers, classrooms, and schools. Intervention in School and Clinic, 43(1), 57-62.

Clark, C., \& Medina, C. (2000). How reading and writing literacy narratives affect preservice teachers' understandings of literacy, pedagogy, and multiculturalism. Journal of Teacher Education, 51(1), 63-76. 
Coakes, S. J. (2005a). Data Screening and transformation. SPSS Version 12.0 for Windows.

Coakes, S. J. (2005b). SPPS version 12.0 for windows: Analysis without anguish (Version. Milton, Queensland Australia: John Wiley \& Sons Australia.

Cochran-Smith, M., \& Fries, M. K. (2001). Sticks, stones, and ideology: The discourse of reform in teacher education. Educational Researcher, 30(8), 3-15.

Cole, R. W. (2008). Educating everybody's children: Diverse teaching strategies for diverse learners. ASCD.

Garmon, M. A. (2004). Changing preservice teachers' attitudes/beliefs about diversity: What are the critical factors? Journal of Teacher Education, 55(3), 201-213.

Garmon, M. A. (2005). Six key factors for changing preservice teachers' attitudes/beliefs about diversity. Educational Studies, 38(3), 275-286.

Gay, G. (2002). Preparing for culturally responsive teaching. Journal of Teacher Education, 53(2), 106-116.

Gay, G. (2010). Culturally responsive teaching: Theory, research, and practice. Teachers College Press.

Gay, G., \& Howard, T. C. (2000). Multicultural teacher education for the 21st century. The Teacher Educator, 36(1), 1-16.

Gibson, E. (2005). Addressing the needs of diverse learners through differentiated instruction (PhD Thesis). Humboldt State University.

Gilligan, R. (2000). Adversity, resilience and young people: The protective value of positive school and spare time experiences. Children \& Society, 14(1), 37-47.

Gorski, P. C. (2009). What we're teaching teachers: An analysis of multicultural teacher education coursework syllabi. Teaching and Teacher Education, 25(2), 309-318.

Grant, C. A., \& Sleeter, C. E. (2006). Turning on learning: Five approaches for multicultural teaching plans for race, class, gender and disability. ERIC.

Gurin, P., Dey, E., Hurtado, S., \& Gurin, G. (2002). Diversity and higher education: Theory and impact on educational outcomes. Harvard Educational Review, 72(3), 330-367.

Hair, J. F., Black, W. C., Babin, B. J., Anderson, R. E., \& Tatham, R. L. (2006). Multivariate data analysis (Vol. 6). Upper Saddle River, NJ: Pearson Prentice Hall.

Handhika, J. (2012). Efektivitas media pembelajaran IM3 ditinjau dari motivasi belajar. Jurnal Pendidikan IPA Indonesia, 1(2).

Hawe, P., Shiell, A., \& Riley, T. (2009). Theorising interventions as events in systems. American Journal of Community Psychology, 43(3-4), 267-276.

Kamal, M. (2013). Pendidikan Multikultural Bagi Masyarakat Indonesia Yang Majemuk. Al-Ta Lim Journal, 20(3), 451-458.

Ladson-Billings, G. (2009). The dreamkeepers: Successful teachers of African American children. John Wiley \& Sons.

Lareau, A. (2011). Unequal childhoods: Class, race, and family life. Univ of California Press.

Lee, O., \& Buxton, C. A. (2010). Diversity and Equity in Science Education: 
Research, Policy, and Practice. Multicultural Education Series. Teachers College Press.

Lickona, T. (2009). Educating for character: How our schools can teach respect and responsibility. Bantam.

Manning, M. L., Baruth, L. G., \& Lee, G. L. (2017). Multicultural education of children and adolescents. Taylor \& Francis.

Matuszny, R. M., Banda, D. R., \& Coleman, T. J. (2007). A progressive plan for building collaborative relationships with parents from diverse backgrounds. Teaching Exceptional Children, 39(4), 24-31.

McAllister, G., \& Irvine, J. J. (2000). Cross cultural competency and multicultural teacher education. Review of Educational Research, 70(1), 3-24.

Milner, H. R. (2005). Stability and change in US prospective teachers' beliefs and decisions about diversity and learning to teach. Teaching and Teacher Education, 21(7), 767-786.

Ming, K., \& Dukes, C. (2006). Fostering cultural competence through schoolbased routines. Multicultural Education, 14(1), 42.

Neal, L. V. I., McCray, A. D., Webb-Johnson, G., \& Bridgest, S. T. (2003). The effects of African American movement styles on teachers' perceptions and reactions. The Journal of Special Education, 37(1), 49-57.

Pang, V. O. (2001). Multicultural education: A caring-centered, reflective approach. ERIC.

Perkins, R. M. (2012). The multicultural awareness, knowledge, skills and attitudes of prospective teachers: A quantitative and heuristic phenomenological study ( $\mathrm{PhD}$ Thesis). University of Missouri-Kansas City.
Ramsey, P. G. (2004). Teaching and learning in a diverse world: Multicultural education for young children (Vol. 93). Teachers College Press.

Renganathan, S. (2009). Exploring the researcher-participant relationship in a multiethnic, multicultural and multilingual context through reflexivity. Qualitative Research Journal, 9(2), 3-17.

Rogers, B. (2015). Classroom behaviour: a practical guide to effective teaching, behaviour management and colleague support. Sage.

Saleh, S. R., \& Doni, C. P. (2018). Penanaman dan implementasi nilai pendidikan multikultural (studi kasus di Universitas Muhammadiyah Gorontalo). Education Journal: Journal Educational Research and Development, 2(1), 41-58.

Saravanamuttu, J., \& Wah, F. L. K. (2006). Political culture in Malaysia: Contesting developmentalism in a multi-ethnic society. In Proceedings of 20th IPSA world congress.

Seefeldt, C. (1993). Social studies for the preschool-primary child. ERIC.

Sekaran, U., \& Bougie, R. (2016). Research methods for business: A skill building approach. John Wiley \& Sons.

Smith, E. B. (2009). Approaches to Multicultural Education in Preservice Teacher Education: Philosophical Frameworks and Models for Teaching. Multicultural Education, 16(3), 4550.

Swee-Hock, S. (2015). The population of Malaysia (Vol. 514). Institute of Southeast Asian Studies.

Tarman, I., \& Tarman, B. (2011). Developing effective multicultural practices: A case study of exploring a teacher's understanding and practices. Journal 
of International Social Research, 4(17).

Terenzini, P. T., Cabrera, A. F., \& Bernal, E. M. (2001). Swimming against the Tide: The Poor in American Higher Education. Research Report No. 20011. College Entrance Examination Board.

Villegas, A. M., \& Lucas, T. (2002). Preparing culturally responsive teachers: Rethinking the curriculum. Journal of Teacher Education, 53(1), 20-32.

Wati, S. (2013). Urgensi pendidikan agama Islam dalam pengembangan nilai-nilai multikultural. Al-Ta Lim Journal, 20(1), 336-345.

Weinstein, C. S., Tomlinson-Clarke, S., \& Curran, M. (2004). Toward a conception of culturally responsive classroom management. Journal of Teacher Education, 55(1), 25-38.

Wentzel, K. R. (1998). Social relationships and motivation in middle school: The role of parents, teachers, and peers. Journal of Educational Psychology, 90(2), 202. 